\title{
Synergity of the Historic Building to the Progress of Tourism in the City of Makassar, Indonesia
}

\author{
Ahmad Husain $\mathrm{MSi}^{1}$ \\ ${ }^{1}$ University of Makassar Pepabri lecturer, Indonesia \\ Correspondence: Dr. Ahmad Husain MSi, Lecturer at University of Makassar Pepabri, Indonesia.
}

Received: July 2, 2019

Accepted: December 18, 2019

Available online: December 24, 2019

doi:10.11114/ijsss.v8i1.4664

URL: https://doi.org/10.11114/ijsss.v8i1.4664

\begin{abstract}
The type of qualitative research through the phenomenological approach, the results showed that historical buildings have an appeal for domestic and foreign tourists, so it is necessary to preserve historical buildings Professional who supported some correct information and informant can understand the historical plot of the building, so that it can provide information to the tourism visitors in the city of Makassar.
\end{abstract}

Keywords: preservation, tourism, synergy, historic, building

\section{Background}

Makassar, which inhabited 1.7 million inhabitants and inhabited an area of $175.77 \mathrm{~km} 2$. Makassar has a coastline that is $35 \mathrm{~km}$ long, with 12 islands. Makassar's economic growth amounted to 7.82\% in 2016 with USD 3,500 per capita income. The recognition of Makassar as one of the main tourist destinations in Indonesia is derived from the Ministry of Tourism which has established it as 1 of 10 cities branding overseas market destinations."As a tourist destination area. Tourism potentials that Makassar has to offer are very diverse. Ranging from historical, maritime, cultural, culinary, and educational tourism, "said Danny.Makassar tourism support facilities are also very promising. Makassar has five major hospitals, as well as 200 starred and non-star hotels. The number of tourism workers certified in the year 2016 reach 2,868 workers who serve 4.6 million tourists archipelago and 85,644 foreign tourists. In addition, Makassar tourism is also supported by the development of creative industries that reach 3,113 community actors. They were creative in the 436 creative industries of Makassar.

In 2017, Makassar Tourism focuses on the development of competitive tourist destinations. The tombs of the Tallo kings, Lae-Lae Island, Samalona, and KodingarengKeke are selected as the flagship tourist attraction.Coincided with it, also developed the tourism village of Lakkang, and the village of Paropo culture. Throughout the year 2017, Makassar will host 4 international events plus 18 monthly tourism events that start running since January. NIA

Indonesia has many historical relics scattered throughout Indonesia, there is a long history barrage that has a story and unique to the community, evidence of historical buildings are still many standing firmly Colonial government in the period of 350 years. The existence of historical buildings can be a government office, a school of nobility or a prison building for the rebels. Then in the time after Indonesia became independent building the building switch function began to be used for office Government of the Republic of Indonesia or demolished for better city development.

As the progress of the science and the mind-set of society today gives a view to the historic buildings of colonial relics or the kingdom period in Indonesia which considers the building to be part of civilization and the cultural identity of a nation and has historical value. Historical building buildings or so-called cultural heritage objects are currently governed by the Nomor11 Law of 2010 on Cultural Reserve explained that cultural heritage objects are objects of nature and/or man-made objects, whether moving or not A unity or group, or parts of it, or the remainder of which has a close relationship with the culture and history of human development. It is further explained in section 88 paragraph 1 that 26 governments, local governments, and anyone can utilize the cultural reserve for the benefit of religion, social, educational, science, technology, culture, and tourism today the reserve object Culture is widely utilized as a tourist attraction because of the increasing needs of cultural tourism activities declared MacDonald (2004 in Pitana and Diarta, 2009:32

Tourism in Indonesia is experiencing a considerable development of the need for the importance of the understanding of 
culture, culture, and the circumstances of a society and other knowledge, encouraging the outside community to come to visit in a Region or country, Indonesia that is rich with historical sites have a unique attraction for the domestic and foreign tourists (foreign tourists) tourism activities has evolved into a mega business and is a One of the largest sources of income in the country. Millions of people issued trillions of American dollars, leaving home and work to satisfy or self-happy (pleasure) and to spend leisure time (recreational) cultural tourism is one of the factors of tourist pullers that Raising the characteristic culture of the region as a tourist attraction cultural resources that can be developed into tourist attraction (Pitana and Diarta, 2009:7 4) among others: historical buildings, monuments, contemporary sculpture art, architecture, crafts Hands, art, religious relics, way of life and local community activities, travel to historic places using unique transportation tools and try and make or serve the culinary community. The existence of historical buildings, sites or monuments is a potential for the development of heritage tourism or cultural heritage tourism as an alternative to urban tourism development. According to Pederson (2002, in Southall and Robinson, 2011:177) Heritage tourism as embracing both eco-tourism and cultural tourism, with an emphasis on conservation and cultural heritage through such definitions it is explained that cultural heritage tourism can embrace ecotourism and cultural tourism at the same time and to engage in conservation and cultural heritage itself. The development of cultural heritage tourism in urban areas is ideal to be carried out because a city will not be 27 lose the local identity and give understanding and sense of pride to the history of the city and local culture of the community.City in Indonesia has a good historical building which is the legacy of the Kingdom era or relics of the colonial period. One of them is the old town with historical stories, traditional culture that is potentially a tourism resource.In the past, the city of Makassar led by the twin kingdoms of GowaTallosteeringAn in the year 1511 Portuguese anchored in Makassar. The Portuguese had spread Christianity, traded and opened the great Portuguese as a great people. The Portuguese arrival was eventually followed by several other nations, such as the Netherlands, England and China with the aim of trading.In the end the Netherlands monopolized the trade and seizedthe royal power of GowaTallo of Makassar with the Politics of sheep (Tika et al, 2013:17) Some of the Dutch relics that still stand today which was then functioning as an office Government or tourist attraction. City Hall Street building characterized by bold: research site Source: Regulation of the Minister of Culture and Tourism. 2010 some buildings. In one of the seminars in the city of Makassar MeutiaHatta who appeared as a speaker stating if you want the city of Makassar to the city of the world, the local government should maintain cultural culture and if the government of Makassar want to give the best like The slogan to the world city should have the principle that the Government must pay attention to poverty, the welfare of the people and keep the culture of one of them is a building that is considered very bersejarah1. The statement confirms that the world city slogan is not a modern facility but how technology advances can be applied to the utilization of historical buildings so as not to diminish the culture and history and bring Welfare for society. Tourism is one of the roads in preserving the building

History in the city of Makassar so it has economic value to help its preservation.

Problem Formulation

1. What is the condition of the historic building in Makassar

2. How many historical building impacts to foreign tourists visit in Makassar City

3. Supporting factors and inhibitory factors affecting increasing number of tourists

\section{Foundation Theory}

\section{A. Tours}

Tourism is a travel activity or part of which is done voluntarily and is temporary to enjoy the objects and attractions (UU No. 9 yrs. 1990 article 1).

The understanding of tourism contains elements i.e. travel activities, conducted voluntarily, temporary and travel entirely and partly aimed at objects and attractions on the basis of the ' tourism ' is the activity Travel or part of the activity voluntarily and temporarily in order to enjoy the objects and attractions (UU No. 9 yrs. 1980 article 1). Objects and tourist attractions are the targets on the tour which include:

A) Such as natural scenery, beautiful panorama, jungle forest with the creation of God YME, which is the nature and flora and fauna of tropical forest plants and rare animals.

b) The works of Human history Museum relics Cultural Art of Argo Tourism (agriculture) Tourism Tirta (water) Adventure Tourism theme park and entertainment venues

c) The target of special interest tourism such as hunting, mountaineering, cave, industrial and handicraft, shopping places, river of heavy water, places of worship, places of direction. (Travel conscious guide book)

According to Mathieson and Wall (Muhammad Aksyar, 2012) that travel is the activity of traveling from and to other destinations outside of his residence, tourism or recreation is often done to be happy or relax. Relax is an activity that is 
different from the activity of performing a particular job. For example during do a job then we sit safe then this can be said to be relaxing.

\section{B. Tourism}

Tourism is etymologically derived from the word "Pari" which means spinning spin and "travel" which means travel. On that basis, tourism is interpreted as a way of turning from one place to another (Yoeti A. Oka,1982:103 in Muhammad Aksyar, 2012).

According to Prof.One of the terms in his book, An Introduction an tourism Theory, suggests that the boundaries of tourism should show the anatomy of the symptoms of the three elements of human beings, people who travel in tourism, Space (space), which is the area or ruing scope of time travel (time) is the time spent during travel and level in the tourist destination area (Yaoti A, Oka: 106 in Muhammad Aksyar, 2012).

Based on the three elements above, Prof. False Wahab formulates the understanding of tourism as a conscious human activity and has the service of the people in a country itself (abroad) that Include the establishment in another area (a certain area, a country or a continent) for a while in search of a wide range of contentment and is different from that in its nature where he obtained a steady work.

In other sense tourism (TOURSNM) is a journey made for a while held from somewhere to another, with the intent not to strive or make a living in the place visited, but solely To enjoy the journey to fulfil its wide range of desires (Yaoti A, Oka: 09 in Muhammad Aksyar, 2012).

C. Tourism Facility (facility and facility)

Facilities and tourism infrastructure is a complement to the tourist destination that is required to serve the needs of tourists in enjoying their travel tour. Development of tourism facilities and infrastructure in the area of tourism destinations and certain tourism objects must be adjusted to the needs of the tourists both quantitatively and qualitatively, more than that market taste can also determine the demands of facilities and infrastructure Tourism (in TomyAhmadi, 2012).

Tourism facilities as the spearhead tourism tourist can be interpreted as a business that directly or indirectly provide services to tourists in a tourist destination where the existence of very dependent on Tourists to travel activities. The facilities are as follows:

\section{A. Accommodations}

Accommodation is a chain of tourist activities. Hospitality cannot be separated from tourism. Without tourism activities can be said hospitality accommodation will be paralyzed, on the contrary, tourist without a hotel is a thing that is not possible, especially when we speak tourism as an industry.

Tourists will need a temporary stay during the trip to be able to rest. With this means it will encourage tourists to visit and enjoy the objects and attractions with a relatively longer time. Information on this property affects traveller ratings of selected accommodation types, such as the type of facilities and services provided, price level, number of rooms available and so on.

\section{B. Places to eat and drink}

Tourists who visit to a tourist attraction certainly want to enjoy their trip, so that the food and beverage service must support, it is very important for tourists who do not bring the stock. Even if a tourist destination has a typical food, tourists who come in addition to enjoy the tourist attractions also enjoy the typical food or it can be the main purpose of enjoying the typical food only. The necessary considerations in the provision of food and beverage facilities among others are the type and the food offered, the level of food and beverage quality provided, the price level, the level of hygiene, other things that can add to the One's appetite and the location of the food. Usually the location is associated with the accommodation and its tourist routes.

\section{Shopping}

Shopping is one of the tourist activities and some of the spending of tourists in distribute for shopping. The assessment in the provision of this shopping facility is done to the availability of goods sold and adequate service, convenient location and good access and relatively affordable price level.

D. Public facilities on site attractions

Common facilities to be examined in general research are the usual facilities available in recreation places such as:

1) Parking space

2) Public WC 
3) Musholah/Mosque

4) Means of information and directions Board

5) Recreation facilities and playgrounds

6) Public phone

The tourism means quantitatively refer to the number of tourism facilities that must be provided and qualitatively show the quality of service provided and reflected in the satisfaction of tourists who obtain the service.

\section{Accessibility}

Accessibility is a function of distance or level of ease to reach the tourist area with various tourist destinations related to the system of movement in the transportation system in a region. This is different from the hypocritical industry, where the goods (products) can be sent to consumers then in the tourism of consumers (tourists) must come to the area where there is a tourism product to consume products, especially the object of tourism and tourist attractions.

Therefore the level of ease of achievement towards the tour will affect the development of tourist areas. The distance and the availability of transportation facilities and infrastructure in the tour are paramount. The type, volume, tariff and frequency of transport modes to and from the tourist area will affect the number of tourist arrivals. Convenience during the trip to the tourism area and the tourist areas must be considered.

\section{Promotions and Information}

Information, one of the important components of tourism component is the existence of travel information, this information can be presented in the form of maps, user manuals, articles in magazines, brochures or via the Internet. Promotion is an important activity in the development of tourism that can be done by the government and private sector, this promotion can be done by placing advertisements, through PR activities and giving incentives for example Admission ticket.

The promotion of a tourism product that is done by visitors, among others, is done by exchanging information, various word of mouth experience to the people around him. Experience or satisfaction of someone who has enjoyed a product or travel is a most powerful media to make promotional media in the form of by mouth promotion the most trusted Truth (Yusuf, 2003). Thus, visitors also have the role of the participation in the promotion to an object and tourist attraction, indirectly as an agent in the promotion (Agent of promotion).

\section{Tourism Product Development}

Development of tourism products is the development of components of its products. The product development is an effort to create products that are better and different than before (making the product newer).

The development of tourism products is interpreted as adding the components of tourism products that have been located in a tourism object. The development itself is able to provide terms of service that suits the tastes of tourists. Lack of supervision and control efforts in some tourism objects caused the deterioration of the quality of existing tourist products. Therefore in the development of tourism products is very important for the increase of quality of tourism products need to be done to improve the image that "travel products are cheap, therefore the quality is ugly" into "tourism products are quite qualified Although the price offered is relatively cheap "(Nursusanti, 2005 in TomyAhmadi, 2012).

\section{Promotions}

Wursanto (Budi and Agung, 2012) The promotion means progress, forward, giving higher status of appreciation. Heldjrachman (Budi and Agung, 2012), said the promotion is a move of another position that has higher status and responsibility, usually be appointed with the increase of wages, salary and other rights.

1. Strategy in conducting the right promotion

According to Beatrix (Etty et al., 2013) The promotion can be ineffective when one chooses the media. Not necessarily a medium with high credibility and a lot of costumer according to our event audience. Many happen, ads already have a huge cost, but it is not able to capture the intended audience. Therefore, to make the appropriate publication and promotion for an event, it is worth considering a few things as below:
a) Segments
b) Location
c) Time and frequency
d) Size 
e) Media Type

f) Cost considerations

g) When required

h) Eye-catching material design

2. Promotion method

The methods that can be used in the promotional activities of an event consist of the following:

1) Advertising (advertising)

A) Print Media

b) Electronic Media

2) Personal sales/salespeople

3) Community Relations/Publicity (Public Relation)

3. Personal Selling Promotion

Personal selling promotion in Badholahi Mustafa (Ayu et al., 2013) is a communication mechanism into two-way communication marketing by utilizing public relations techniques. According to Dali ourBubujevic in his journal titled Position and Role of Personal Selling in Contemporary Marketing Management. The definition of Personal selling is the oldest instrument in the promotion that uses the techniques between sellers and buyers.

According to Philip Kotler (Ayu et al., 2013) Personal selling has three special traits:

A) Personal confrontation.

Personal selling includes a lively, direct and interactive relationship between two or more people. Each party can see the needs of the other party's characteristics in a closer and immediate adjustment.

b) Response.

Personal selling makes the buyer feel obligated to hear, pay attention, and respond to the salespeople.

c) Development (cultivation).

Personal selling allows various types of relationships ranging from sales relationship to friendship relationship.

Which means that personal selling is an involvement through direct communication with potential customers through the process of establishing a relationship, detecting the need and packing the product to suit its needs. It is also a process to inform the good of the musicians in the provision of data, reminding and convincing users.

Personal selling promotion strategies can be described as follows:

A) a librarian's power to the settlers is a direct sale made by one salesperson to a prospective consumer. Usually this activity is called the pickup ball from the librarian to the musicians.

b) The power of the librarian to the group of settlers is a direct promotional offer made by a single librarian to a group of aspiring musicians assembled in a particular place.

c) The librarian team to the buyer group is a direct promotional offer made by a group of librarians to a group of aspiring musicians gathered in a particular place.

D) Promotional offers through the same is a direct promotional offer made by utilizing seminars or when learning activities if it happens in a school.

E. Marketing

In defining marketing we can distinguish between social and managerial definitions for marketing. By social definition, marketing is a social process whereby individuals and groups get what they need and want through the creation, offering, and service of freely valued products and services with others (Philip Kotler, 2002). As a managerial definition, marketing is often described as "snivelling products". "But Peter Drucker, a leading management theorist, said that" the marketing objective is to make excessive sales. The marketing objective is to know and understand the customer well so that the product or service matches him and sells himself (Philip Kotler, 2002).

Marketing is a management process to identify, anticipate and satisfy customers ' needs profitably. Marketing is the process of planning and implementing conception, pricing, promotion and distribution of ideas, goods and services to create a satisfying exchange of individual and organizational objectives. These two definitions reflect, a traditional transaction-oriented view of marketing. They do not contain explicit recognition of the customer's long-term value. The 
theory has begun to develop alternative definitions that capture the nature of new marketing. Gronroos (1990, 1991; 1994, p355), for example, offers the following: "Marketing is to build, maintain, and improve relationships with customers, and other partners, on profit, so that the parties involved are met.

Case studies relate to marketing in the form of relationship dependency, trust, commitment, communication, cooperation, and equity. Researchers in marketing have a tradition of map checking dependence in consumer-seller relations. In the Works of Emerson (1962) and Beier and Stern (1969), Frazier (1983) in Jeffrey E. Lewin and Wesley J. Johnston (1997) proposed that the buyer's dependence on sales is directly related to the consumer's need to sustain Contact with the order to achieve the desired objectives (eg, profit, supply Source, customer service).

Heide and John (1988) in Jeffrey E. Lewin and Wesley J. Johnston (1997), identifying four situations at the end of the buyer's increase in suppliers: (1) The insignificance gained from consumer-critical relationships is highly appreciated, and/ Or the magnitude of the exchange is high, (2) when the relationship affords the consumer a relatively better benefit compared to the benefits of an alternative relationship, (3) when some potentiation alternative sources of exchange are available, and (4) the type is deemed either difficult or costly to replace the incumbent supplier.

Formal studies of marketing focuses on initially Ondistributionand exchange of commodities and production products and display a foundation in the field of economics (Marshall 1927; Shaw 1912; Smith 1904 in Stephen L. Vargo and Robert F. Lusch, 2004). Initially the marketing scholars directed their attention to the Commodore of the Exchange (Copeland 1920 in Stephen L. Vargo and Robert F. Lusch, 2004), the supply Agency made the goods available and arranged for ownership (Nystrom 1915; Weld 1916 in Stephen L. Vargo and Robert F. Lusch, 2004), and the functions that will be undertaken to facilitate the exchange of goods through marketing (Cherington 1920; Weld 1917 in Stephen L. Vargo and Robert F. Lusch, 2004).

\section{Research Methods}

Based on the type of research which uses qualitative research methods, Phenomenology Research Approach, Data sources in this study include: Primary Data Sources, Secondary Data Sources. This research instrument is the researcher himself, the techniques of data collection used are: In-depth interview techniques using interview guidelines, observation, documentation. Validation of data is done by: Extension of observation, Increased perseverance of researchers in observations and interviews, Triangulation of sources. Data analysis techniques used are: data collection) carried out after drawing conclusions based on the problem and purpose of the study, to obtain propositions, statements or resumes as research findings that can apply in general. Data reduction), for the sake of simplifying data in order to sharpen data needed. data display) in an organized and systematic manner, so that it forms one complete and integrated component. drawing) that is verifying the data obtained to find meaning, noting the regularity of patterns, causal relationships that might be used as a very loose conclusion remains open, and draws final conclusions.

\section{Discussion}

Various efforts to preserve historical relics have been done by the government, it aims to keep the value of authenticity of the building, in addition to the improvement, restoration and effort to improve the building Historical does not mean to change its original but it is done to extend the quality of the building in order not to rapidly fragile (destroyed) conservation efforts that have been done first and now basically have the same purpose, namely Preservation in the interests of the excavation of cultural values and processes that have occurred in the past and its development to the present and preservation of cultural heritage objects because of its value to a historical event that has occurred in Past. But along with the ongoing development efforts in our country, it gives a challenge to the preservation effort. Development often has a negative impact on the sustainability of cultural heritage objects. This Problem arises everywhere especially in urban areas. Development activities without regard to the existence of cultural heritage objects until now still ongoing. This is seen from the declining quality and quantity of cultural heritage objects, to succeed the preservation need to involve various stake holders, community leaders, academics, educational world, tourism office and all components of the community Historical building conditions in the city of Makassar

Makassar city has a lot of historic buildings, but its existence has undergone many changes, where the buildings that have historical values tend to be replaced by new buildings and switch functions to hotels, restaurants, housing, etc. This is caused by government policies that tend to change due to changes in regional heads and new officials, besides that many people in the city of Makassar are not interested in learning about the meaning behind historical buildings, this also has an impact on the next generation as if historical buildings are considered less important to be preserved. even so, there are still efforts made by observers of historical buildings to maintain the existence of these buildings, in this case the tourism department is formed by the government to preserve and preserve historical buildings that have historical value, wisdom values okal from the ancestors of freedom fighters who lived a few generations ago, but in reality tourism services cannot be relied on to maintain and preserve tourism in the form of maintaining buildings so that they can be valued in the community but need to involve other institutions, need to involve the world of education, stake holders, the government 
and all levels of society, as for the historic wake that still stands today are as follows:

The Fort Rotterdam

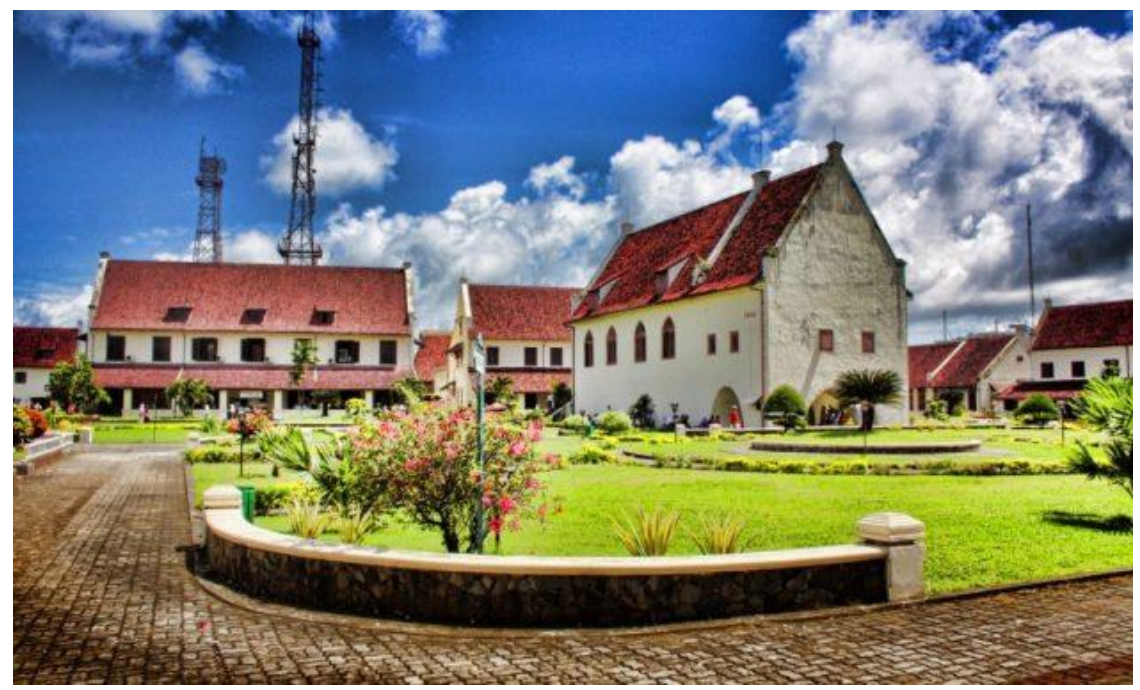

Fort Rotterdam was established in 1545 by the king of Gowa X named ImanrigauDaengBontoKaraengLakiung or KaraengTunipalanggaUlaweng. Fort Rotterdam is located on Jl Ujung Pandang is where the king and his family settled. The usual fortress is also called Jumpandang (Ujung Pandang) is shaped like a turtle tail that crawls down to the sea. It means philosophical that the kingdom of Gowa, Jaya (Great) in the land and in the ocean. This fortress then fell in the Dutch hands in 1667 through the Bongayya Treaty. The treaty was signed after the reigning King was defeated in battle. The name was changed to Fort Rotterdam after repair, by the Dutch. This time, with the style of European architecture of the time and done by the artists, not the artisan.

Fort SombaOpu

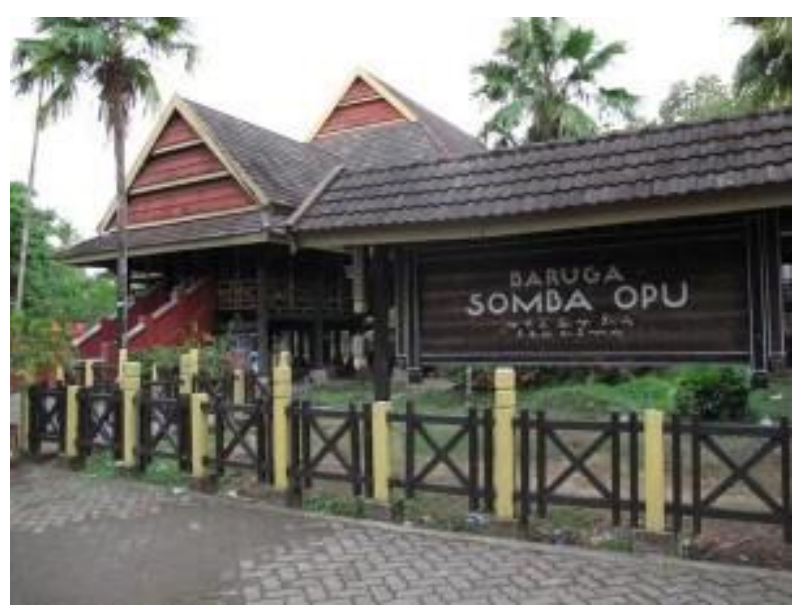

indonesiaexplorer.net

Fort SombaOpu is the fortress of the Sultanate of Gowa, built by the 9th king of GowaDaengMatanreKaraengtumapa'risi ' Kallonna in the 16th century. It is said that BentengSombaOpu located in Daeng Tata Street, Makassar Sub-district is the first in addition to functioning as a fortress is also the centre of the Government of Gowa kingdom. In the fortress, we can still see the buildings that are likely the relics of the Kingdom of Gowa. Even now inside the castle complex is being developed a mini garden for South Sulawesi.

Societies de harmonies

Societies de harmonies was built in 1896 by the Dutch colonial government. The architecture of the building located on J1 Ahmad Yani is Neo classical style. Built on a land area of 2,339 square meters. The dens are shaped like the letter "L" and are equipped with a tower with a dome-shaped roof. In the first place, the building was built to meet the needs of meetings, 
gatherings, parties, showmanship, music and other official events. All the events were attended by the important guests and the Dutch high-level at the time. Now, the building is still used as a venue for dance and theatre performances. In addition, as a showcase of various fine art products such as paintings, sculptures, and photographs.RadioRepublic Indonesia (RRI) MakassarLive radio stations were built by the Japanese government just when they first occupied Makassar, 8 December 1942. His name is MakassaruHozoKyoku, abbreviated MHK. His first broadcast was a speech from Admiral Suddo Kane Omi. And of course to strengthen its position, the broadcast contains However, the radio station on JIRibura'ne then switched to Kamarsayah, Sutoyo, and Muritib from Jakarta, May 1950. And finally controlled by the Indonesian National Army, 18 August 1950, and still airs today.

Fort SombaOpu

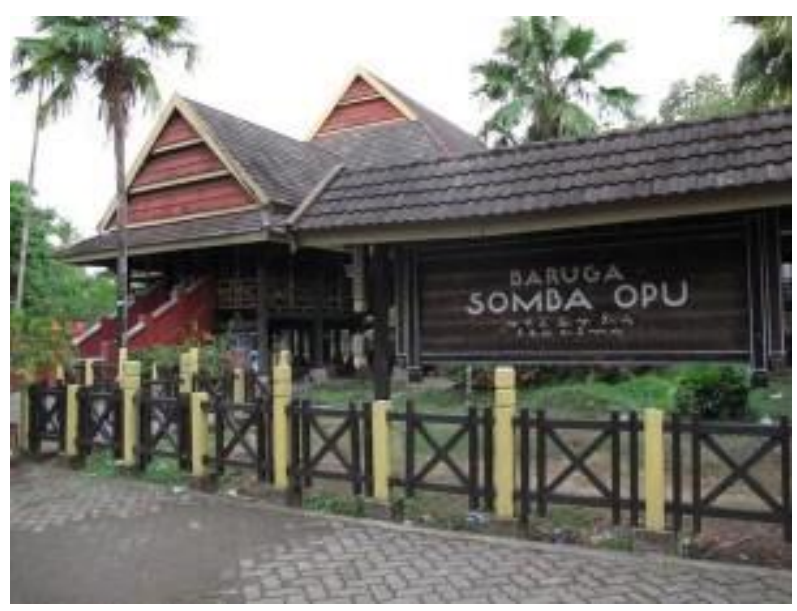

indonesiaexplorer.net

Fort SombaOpu is the fortress of the Sultanate of Gowa, built by the 9th king of GowaDaengMatanreKaraengtumapa'risi ' Kallonna in the 16th century. It is said that BentengSombaOpu located in Daeng Tata Street, Makassar Sub-district is the first in addition to functioning as a fortress is also the centre of the Government of Gowa kingdom.

In the fortress, we can still see the buildings that are likely the relics of the Kingdom of Gowa. Even now inside the castle complex is being developed a mini garden for South Sulawesi.

Makassar City Museum

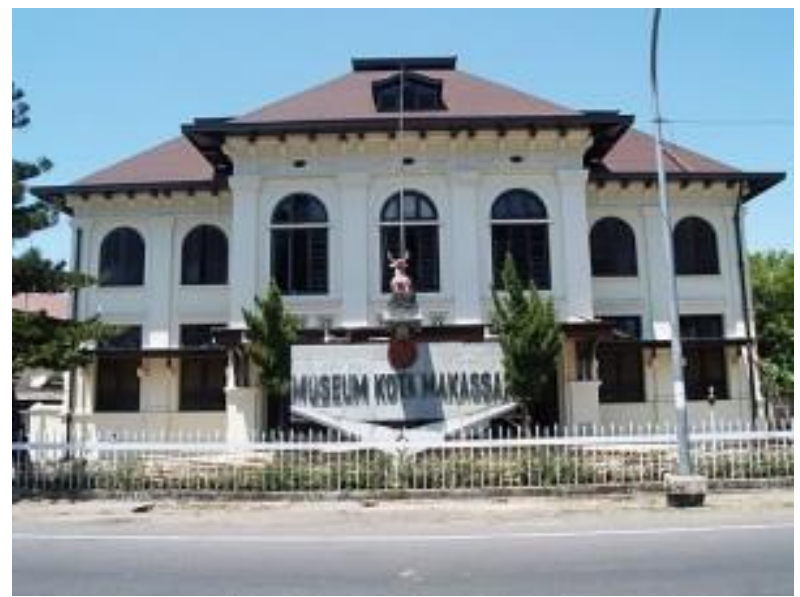

Originally, the building was called Raadhus van de Gemeente or mayor's office. None other than because this building serves as the office of the mayor. For the first time, Makassar was led by a Dutch mayor named JE Dan Brink. The building is also built based on Dutch architectural tastes. June 2000, under the leadership of HB Amiruddin, the building turned into a museum function. There are various historical collections in it. To know the city's timeline, you have to walk through the museum on JlBalaikota starting from the left side of the museum entrance.

Makassar District Court

Makassar District Court. This building is one of the buildings that also remains Dutch. This building used to be the seat of a court assembly under the leadership of the Justisi officer named Baljauw. His name was College van Schepennen as Schepenbank. This Assembly serves to prosecute the residents of any nation city. Similar to Societies de harmonies, the 
building is also built in the architectural style of Neo classical European mix, Renaissance and Roman.

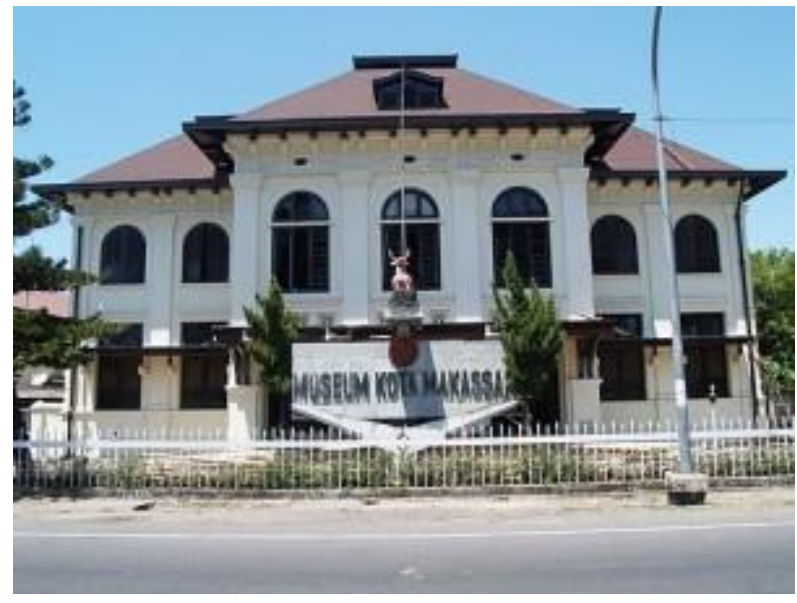

B. Historical buildings and potential tourist arrivals in the city of Makassar

In the year 2018 Makassar city is visited by tourists both from domestic and abroad, which amount to the increase of significant, at 2017 tourist visits reach 2,378,035 people. Where domestic tourists visit as much as 2,324,619 people and foreign tourists, 53,416 people. Meanwhile, domestic tourists visit as of 1 January to 30 June 2018 for 2,550,750 people. And foreign tourists reach 53,764 people. So, the total tourist visit reaches 2,605,334 inhabitants. This Nominal is revealed in tourism sector analysis activities: tourist arrivals in the city of Makassar (January-June 2018) initiated by the Makassar tourism office at Hotel D'maleo, JalanPelita Raya. Thursday (26/7/2108).

The visit of the foreign tourists (Wisman) who are in the city of Makassar in January 2019 dropped 1.57 percent annually. The Central Statistical Board of Sulsel released the data, during January Wisman recorded 839 visits. As of January last year 826. That is, there is a decline of about 13 visits or 1.57 percent. Head of the distribution statistics field of the central Statistical Agency (BPS) Sulsel, Akmal said, on a monthly basis, the number of Wisman decreased by 40.33 percent compared with the number of Wisman in December 2018 which reaches 1,406 visits. The task of head of the Culture and Tourism Office of Sulsel, Nuryadin said, when comparing the visit between December 2018 and January 2019 there is a decline. "This is due to January 2019 is a low session especially Wisman, " He said. But in February, he was optimistic to increase with the direct flight Kuala Lumpur-Makassar with Air Asia whose flight is only 4 times a week, as of February become every day "with the direct flight every day from foreign visits to Makassar Expected to have positive effect on increasing the number of visitors to South Sulawesi, so it will excite the tourism sector of South Sulawesi,"he said. He assessed, if international access is more so it will facilitate the tourism industry in this case make a travel bureau (BPW) to sell the destination Sulsel. As known, during the Malaysian Wisman dominates with 575 visits, Singapore 43 visit, Germany 25 visits, United States 24 visits, and Australia 21 visits. The five countries contribute to the largest number of foreign tourists who visit Indonesia through Makassar's entrance (Hasanuddin Airport) during January. The number of visitors from five countries amounted to 688 visits or about 82 percent of Total Wisman entered through the entrance of Makassar. (Tribune-Timur. comET 2019 MARCH)

3. Synergetic in building Heritage tourism in Makassar City

Regional genuine income (PAD) tourism sector is from Hotel tax, restaurant/dining and Entertainment house year 2014 with the following details:

Hotel Tax: Rp. 75,164,615,000

Restaurant tax/dining house Rp. 75,115,785,000

There are seven challenges faced in the management of tourism of Makassar City: first, increased security guarantee against tourists. Secondly, the cleanliness and the beauty of the destination. Thirdly, T creates public hospitality towards travellers. Fourth, the availability of supporting facilities and infrastructure as a world city.Fifth, empowerment of the creative economic industry business.Sixth, community participation in the development of creative economy. And the seventh, unique event and become a tourist attraction. All sectors related to tourism in South Sulawesi, must collaborate to support an inclusive and sustainable growth.

Chairman of Indonesia Hotel and Restaurant Association (PHRI) SulselAnggiatSinaga to reporters, explained, many indicators that determine the high level of tourist visits to the area.From facilities, accessibility, hospitality, resorts in the area, to its natural potential." For hospitality, we are difficult to compete with Yogyakarta to Bali, from the resort side, "he 
explained, during the press conference PHRI Award at Hotel Claro Makassar, Monday 26 November 2018.

While the resort side, certainly not just the task of hospitality industry. A good Resort (recreation and relaxation) needs the support of others: the cultural community, the supporting natural potential, and the contributions of other sectors. Previously, Anggiat revealed that tourism relies heavily on synergetic and collaboration between sectors, ranging from hospitality industry, restaurant, tour and travel organizer, government, media, to community.

The concept of collaboration was previously proclaimed by the MenparAriefYahya, carrying the Synergy name ' Pent helix '.

According to him, hospitality and restaurants are sectors that support a lot of economic growth that is significant in Sulsel. " The hotel industry and restaurants for example, which accounted for the second largest PAD (indigenous revenue area), "he said.

\section{The Charm Of Makassar City}

Makassar is rich in tourism objects, ranging from historical tourism, maritime, to culinary. To improve the attraction of the tourist attraction, the city government of Makassar continue to ImproveMakassar City has a variety of tourist attractions are so beautiful and fun to be visited by tourists from different regions and countries, such as the history and culture tour of Fort Rotterdam, Fort SombaOpu, City Museum, miniature Park Sulawesi, Kayangan, Losari Beach, Karebosi, then Diponegoro Tomb, and for modern or artificial tourism objects there Trans Studio Theme Park, Bugis Waterpark, Pantaiakdue, Centre for gold crafts in SombaOpu, the centre of the glove handicraft around Panakukang, Then for marine tourism there is the tourist area of coastal city, Spermonde area such as Lae-Lae, Samalona and Kodingareng, then there are culinary centres that are always visited in almost every corner of Makassar city with a touch of typical areas such as Coto Makassar, dried noodle, Pallubasa, PisangIjo, Banana Epe ', Konro, Lulu there is a souvenir centre on the street SombaOpu, and more.

Makassar will make Sombere ' program, now while the road, Makašarta ' no Rantasa ' so Makassar net, Sombere it how all can"hospitality " (friendly) then the third is smart city, a versatile card that is much faster access and easier to transact in one card (cashless), and then we make the Makassar Monthly Festival, revitalize all tourism objects, design good tourist transport, and then the entire infrastructure of our organization improve all .

First, a destination development program. Second, a at of tourism marketing development, which is the implementation of the promotion of destinations or introducing Makassar City tourism to be well worth visiting by providing information about destinations in Makassar City and supporting facilities Other well-packaged and fixed annual events and other high-quality supporting events that can enhance the appeal of both Indonesian and local tourists andForeign, such as the Losari Festival, Makassar Expo, Makassar culinary, Dragon Boat Festival, folk Game Festival, Jazz music festival Fort Rotterdam, Makassar Marathon, art stage angingMammiri, International Writers Festival, International Sea screen and many more events Conducted by the Government or other parties in various forms of activities in the field of performing arts, sports, education and health and other things that annually held in the city of Makassar.

Third, creative economic development Program, which is the engagement and empower all the arts and culture as well as the creative economic industry in the implementation of activities to improve the love of society in supporting the government program Makassar city in particular and Makassar program to the ASEAN Economic Community (MEA) in general, which has high market potential, both in the global market and the domestic market so as to increase the innovation more creative to optimize Aspects of tourism (EKRAF).

Local government packages and sells programs or tourism objects that are through the activities of exhibition promotion tourism in several cities in Indonesia and abroad to introduce and promote tourist attraction in Makassar city, activities Supported by several related stakeholders such as ASITA, PHRI and Makassar City Tourism Promotion Agency (BP2M) by conducting various activities such as Travel Fair which presents the buyers and sellers (sellers) from within and Foreign countries to introduce and sell tour packages in Makassar City, as well as cooperation activities in the form of tourism events and promotion in and outside the country by the Department of Culture and Tourism of South Sulawesi province Also Ministry of Tourism Republic of Indonesia.

C. Supporting factors and inhibitory factors affecting increasing number of tourists

Promotional activities greatly affect the number of tourists who visit Sul-Sel. But it is inevitable that there are factors that support or inhibit the effort to increase the number of tourists in South Sulawesi

1. Factors that support the implementation of tourism promotion, among others:

\section{A. Things to do}

Makassar is one of the cities selected in the top 10 major tourist destinations and the city ' MICE ' (meeting, Incentive, Convention, exhibition). Certainly just Makassar has fulfilled the requirements as a superior tourism city, the only tourist 
attraction is quite a lot and interesting. The tourist attraction is the creation of God and man made. The attraction is the tourist attraction, the historical tourist attraction, the ' MICE' attraction and many more. In line with the narrative head of the promotion, Drs.SamudraUsman that: "Makassar is one of the top tourist destinations in Indonesia that has various tourism objects that can be visited. In addition, it is supported with Makassar's typical food and interesting tourist attractions. "

\section{B. Facilities and infrastructure}

Facilities and infrastructures have an important role in supporting the number of tourists in Makassar. With the many hotels and improvements in transportation means it will give ease to the tourists in their activities to visit historical building objects. This is in line with the statement of one of the academics who said that without the support of facilities and infrastructure, the presence of tourists is very difficult to improve

Factors that inhibit the implementation of tourism promotion include:

A. Capital

One of the biggest obstacles in building the city of Makassar as one of the tourist areas is the fund factor, when we observe a lot of historical heritage in the form of culture, local wisdom, and historical buildings that have value The history of the highly sought after people from local residents, residents outside of Makassar, as well as overseas tourists,

Makassar city government is not optimal in building a reliable tourism means constraints are financial factors, with limited financial condition then certainly many of the activities that can not walk such as promotion, the establishment of resources Human beings are also constrained when not supported by the power of funds, therefore the progress of tourism will be created when there is cooperation of all stakeholders and support from all walks of life.

\section{B. Human Resources}

Human resources are needed in supporting tourism, many historical buildings in the city of Makassar will be great value when the situation can be told by the public to the tourists both domestic and foreign, in The fact that many people do not know and not able to tell the events related to historical buildings, this is because many people do not try to find out the profile of the historical building, so I want to Convey that building human resources cannot stand alone but must involve the world of education, the related service, and the availability of historical literature will be a building either in writing, as well as the form of files to be disseminated So that people can know, it means that the human resources are superior when always get a touch of science, scientific information and others.

\section{Conclusion}

Historical buildings become important objects in tourism, the presence of historic buildings invites the presence of domestic tourists and foreign tourists who have a sense of curiosity about the conditions, circumstances of the past, historical buildings Scattered in the city of Makassar has its own charm for the tourists, the preservation of historical buildings of important value, which is able to provide information about the condition, the situation of the former people so that the value of positive value Abandoners of the former can be used to study the future generations,

\section{References}

Ayudkk. (2013). Perception of the response to promotion through how to Personal Selling in the library SMA Taruna Nusantara Magelang. Journal of Library Science, 2(2), 1-6.

Budi danAgung (2012). Rotation, mutation and promotion of employees in Klaten Primary Tax Service Office. the competitiveness of the Journal of Economic Resource Management, 13(1), June 2012.

Ettydkk. (2011). Model of the Promotion Strategy exhibition Stand at the company PCO (Professional Conference Organizer). Journal of Economics and Business, 10(2), December 2011.

Francis, B. (1996). Relationship MarketingTheory and Practice. British Library Cataloguing in Publication Data London: Paul Chapman Publishing Ltd.

I Made, S. (unpublished). Preservation of cultural heritage.law Seminar paper at Sriwijaya University Graduate School of Legal Studies Program.

Jagdish, N., \& Shethdan, A. P. (2002). Evolving Relationship Marketing into a Discipline. Journal of Relationship Marketing, 1(1). https://doi.org/10.1300/J366v01n01_02

Jeffrey, E., Lewindan, W., \& J. Johnston (1997). Relationship Marketing A Case Study. Relationship Marketing Theory. Journal of Business Research, 39, 23-31. https://doi.org/10.1016/S0148-2963(96)00152-X

Muhammad, A. (2011). The impact of tourism on the environment.

Philip, K. (2002). Marketing Management, Millenium Edition. University of Phoenix, Boston: Pearson Custom 
Publishing 2002.

Rusmeijani, S. (unpublished). Preservation of the site and cultural conservation in South Sumatera for historical reconstruction, archaeological Heritage Hall Jambi.

Soekmono, R. (1992). "Little History", 50 Years of antiquities and antiquities. National Archaeological Research Center Department of Education and Culture, 1992.

Stephen, L., Vargodan, R., \& F. Lusch (2004). Evolving to a New Dominant Logic for Marketing. Journal of Marketing, 68. https://doi.org/10.1509/jmkg.68.1.1.24036

Surya, H. (Unpublished). The role of historical and archaeological heritage in the protection, development, and utilization of Heritage objects.the paper in the work meeting of coordination duties and functions of UPT in the Environment Directorate General of Culture, Bogor 8-10 May 2000.

The sheen of Sulawesi 2012. Handicraft and Crafts exhibition. Retrieved from www.debindo-mks.com

Tomy, A. (2012). Environmental Science introduction paper (Tourism).

\section{Copyrights}

Copyright for this article is retained by the author(s), with first publication rights granted to the journal.

This is an open-access article distributed under the terms and conditions of the Creative Commons Attribution license which permits unrestricted use, distribution, and reproduction in any medium, provided the original work is properly cited. 